\title{
Alternative splicing to exon 11 of human prolactin receptor gene results in multiple isoforms including a secreted prolactin-binding protein
}

\author{
J F Trott, R C Hovey, S Koduri and B K Vonderhaar \\ Molecular and Cellular Endocrinology Section, Center for Cancer Research, National Cancer Institute, 5B47/10 Center Drive, Bethesda, \\ Maryland 20892-1402, USA \\ J F Trott and R C Hovey are now at the Lactation and Mammary Gland Biology Group, Department of Animal Science, University of Vermont, \\ Burlington, Vermont 05405, USA
}

(Requests for offprints should be addressed to B K Vonderhaar; Email: bv10w@nih.gov)

\begin{abstract}
Endocrine and autocrine prolactin (PRL) exerts effects on normal breast and breast cancer cells, and high serum PRL is a poor prognostic factor for colorectal cancer. Here we tested the hypothesis that short isoforms of the PRL receptor (PRLR) in human tissue regulate the actions of PRL in cancer. Using 3' RACE we isolated five splice variants of the human PRLR ( $h P R L R$ ), three of which encode the complete extracellular binding domain. Two of these isoforms, short form 1a (SF1a) and short form 1b (SF1b), possess unique intracellular domains encoded by splicing to exon 11 from exons 10 and 9 respectively. A third novel isoform $(\Delta 7 / 11)$ reflects alternative splicing from exon 7 to exon 11 and encodes a secreted soluble PRL-binding protein. Additional splice variants of SF1b and $\Delta 7 / 11$ that lacked exon $4(\Delta 4-\mathrm{SF} 1 \mathrm{~b}$ and $\Delta 4-\Delta 7 / 11$ ) were also identified. Functional analyses indicated that hPRLR-SF1b is a strong dominant-negative to the differentiative function of the PRLR long form while hPRLR-SF1a is a weaker dominant-negative. Differential abundance of SF1a, SF1b and $\Delta 7 / 11$ expression was detected in normal breast, colon, placenta, kidney, liver, ovary and pancreas, and breast and colon tumors. Taken together, these data indicate the presence of multiple isoforms of the hPRLR that may function to modulate the endocrine and autocrine effects of PRL in normal human tissue and cancer.
\end{abstract}

Journal of Molecular Endocrinology (2003) 30, 31-47

\section{Introduction}

Prolactin (PRL) is a polypeptide hormone that has a clear role during mammary carcinogenesis in rodents (Wennbo et al. 1997) and may contribute to the initiation and progression of human breast cancer (Hankinson et al. 1999). Serum PRL levels are also a recognized risk factor for recurrence and reduced survival time for both breast and colorectal cancer (Bhatavdekar et al. 1992, 2000, Patel et al. 1994). The effects of PRL may be realized through either the endocrine synthesis of PRL or its local autocrine/paracrine synthesis in various tissues including breast and colon cancer (Clevenger et al. 1995, Ginsburg \& Vonderhaar 1995, Touraine et al. 1998, Bhatavdekar et al. 2000, Llovera et al. 2000). A recent report of a soluble PRL-binding protein present in human serum and milk derived from an as yet unidentified site(s) (Kline \& Clevenger 2001) adds further complexity to the mechanism by which PRL probably acts on normal and neoplastic tissues.

PRL acts through the PRL receptor (PRLR), a member of the large class-1 cytokine receptor superfamily (Bole-Feysot et al. 1998). The PRLR is composed of an extracellular ligand-binding domain, a transmembrane region and an intracellular domain (Kelly et al. 1989). The gene contains ten exons including five alternative exon 1 sequences, where only exons 3 through 10 are coding exons (Hu et al. 1999, 2002). Different isoforms (long form (LF), intermediate form (IF) and short form (SF) of the PRLR have been named for the length of their intracellular domain 
generated by alternative splicing of the PRLR gene (Ormandy et al. 1998, Hu et al. 1999). Functional clones have been characterized for the human (h)PRLR-LF (exons 1 to 10; Boutin et al. 1989) and IF (same as hPRLR-LF but lacks part of exon 10; Kline et al. 1999). The most extensively characterized isoform is the hPRLR-LF that transduces both mitogenic and differentiative signals (Lesueur et al. 1991, O’Neal \& Yu Lee 1994, Jabbour et al. 1998, Llovera et al. 2000).

SFs of the PRLR have been cloned from the rat (Boutin et al. 1988), mouse (Davis \& Linzer 1989), sheep, cow and goat (Bignon et al. 1997) although their roles are largely unknown. Alternative splicing from exon 9 to an exon unrelated to exon 10 generates the rat and mouse SFs. The ruminant SFs are generated by alternative splicing to include $39 \mathrm{bp}$ located 5' of exon 10 (Bignon et al. 1997). The rat short PRLR exerts a dominant-negative effect on differentiative signals transduced by the LF (Berlanga et al. 1997), while the SF in sheep does not transduce a differentiative signal, but is capable of phosphorylating Stat5 (Bignon et al. 1999). The mouse RSl isoform facilitates mitosis in mouse fibroblasts (Das \& Vonderhaar 1995). During the preparation of this manuscript, $\mathrm{Hu}$ et al. (2001) described a novel exon 11 of the human PRLR (hPRLR) gene and two SFs of the hPRLR (SFla and SF1b). These isoforms were shown to be dominant-negatives to the differentiative function of the hPRLR-LF.

In this study we performed $3^{\prime}$ RACE to search for SFs of the hPRLR, assuming similar 3' splicing occurred in humans as in rodents (Bignon et al. 1997, Ormandy et al. 1998). Two SFs of the hPRLR (SFla and SF1b) were cloned from human placenta that led to subsequent cloning of three additional variants $(\Delta 7 / 11, \Delta 4-\mathrm{SF} 1 \mathrm{~b}$ and $\Delta 4-\Delta 7 /$ 11) from breast cancer cDNA. Both hPRLR-SFla and hPRLR-SF1b were shown to function as dominant-negatives to the differentiative effect of the hPRLR-LF, whereas $\Delta 7 / 11$ encodes a secreted, soluble PRL-binding protein. Expression of these isoforms was detected in normal human tissues and breast and colon cancer.

\section{Materials and Methods}

\section{3' RACE}

3' RACE was performed on Marathon-Ready human ovary cDNA (Clontech, Palo Alto, CA,
USA). Three 5' gene-specific primers designed from the hPRLR-LF cDNA (GenBank Accession M31661) were used for 3' RACE. The sequences of these primers were hPRLR2D (5'-GGAGTGGA TGGAGTCGAGCGACG-3') in exon 7, and NhPRLR2e (5'-ATGGTGACGTGGATCTTTCG GCGAGTTC-3') and NhPRLR2c (5'-TGGGCG AAAAATAAAAGGATTTGATGG-3'), both in exon 9. These $5^{\prime}$ primers were used in three rounds of nested PGR. The first round of amplification used hPRLR2D with adapter primer AP1, the second round used NhPRLR2e with adapter primer AP2 on products from the first reaction, and the third round used NhPRLR2c with AP2 on products from the second reaction. Genuine RACE products from the final two reactions were identified by electrophoresis side by side on $1 \cdot 2 \%$ agarose gels. Products from the third PCR were gel-purified and cloned into pCR2.1 (Invitrogen, Carlsbad, CA, USA) prior to sequencing.

\section{Plasmids}

The $\beta$ casCAT plasmid contains 344 bp of the rat $\beta$-casein promoter upstream of the chloramphenicol acetyl transferase (CAT) reporter gene (both gifts from L Hennighausen, NIDDK, NIH, Bethesda, MD, USA). The pEFlacZ plasmid (Invitrogen) contains the elongation factor- $\alpha 1$ (EF) promoter upstream of the lacZ ( $\beta$-galactosidase) reporter gene. The hPRLR LF cDNA, a gift from Paul A Kelly (INSERM, Paris, France), was subcloned into pCRScript (Stratagene, La Jolla, CA, USA) and sequence verified prior to being subcloned into the pEF6C expression vector (Invitrogen). pCMV-GFP contains GFP cDNA under control of the CMV promoter (a gift from David Kerr, University of Vermont, VT, USA).

\section{Cloning of hPRLR cDNAs}

Primers were designed over the ATG translation initiation site (hPRSF2; 5'-AAGAGAAGGCAGGC AACATGAAG-3') and at the $3^{\prime}$ end of the exon 11 sequence (hPRSR2; 5'-TAAGATGGAACGAGGT TGCGAAG-3'). Total RNA (1 $\mu \mathrm{g})$ from human placenta was used for the $25 \mu \mathrm{R}$ T reaction using MMLV-RT (Life Technologies, Gaithersburg, $\mathrm{MD}, \mathrm{USA}$ ) primed with both oligo dT and random hexamers. PGR was performed on $5 \mu \mathrm{RT}$ product using the Advantage cDNA PCR kit (Clontech). 
Reaction conditions were $94{ }^{\circ} \mathrm{C}$ for 1 min then $94{ }^{\circ} \mathrm{C}$ for $30 \mathrm{~s}, 63.5{ }^{\circ} \mathrm{C}$ for $1 \mathrm{~min}$, and $72{ }^{\circ} \mathrm{C}$ for $3 \mathrm{~min}$ for 45 cycles. PGR products were gel purified, cloned into pCR2.1 (Invitrogen) and sequenced in both directions. Fragments with the correct sequence were subcloned into the pEF4C (Invitrogen) expression vector. The $\Delta 7 / 11, \Delta 4$ $\Delta 7 / 11$ and $\Delta 4-S F 1 b$ cDNAs were amplified by PCR using reverse-transcribed breast cancer RNA, gel purified, then cloned into pCR2·1 (Invitrogen) for sequencing to generate a consensus from multiple clones.

\section{Generation of FLAG-tagged PRLR cDNAs}

The hPRLR-LF cDNA was C-terminal tagged with the FLAG epitope using the primers LF5P 5'CACGGGCGACTCTGTTGAATGAAG-3', and LFFLAG3P 5'-CGGTTGGAATGATTTATGGT GATGGTGTTTGTAGTGGTGAAAGGAGTG TGTAAAAC-3' to generate a PGR product encompassing the $3^{\prime}$ coding region of the hPRLR-LF sequence 1621 to 2101 bp (M31661) with a FLAG sequence (bold) inserted prior to the stop codon. The cDNA was sequence verified, then excised from pCR2.1 with XbaI and BstBI and ligated into the similarly digested pEF6 hPRLR-LF construct.

The hPRLR-SF1a, hPRLR-SF1b and hPRLR$\Delta 7 / 11$ cDNAs were C-terminally tagged with the FLAG epitope using the following primers: SF5P 5'-CGCGGATCGAAGAGAAGGCAGCGAACA TGAAG-3' for all constructs plus either SFlaFLAG3P (5'-GCGGGAATTGTGATTTATCGT GATGGTGTTTGTAGTGGTGGACTGTGGT CAATGTTG-3') for both hPRLR-SFla (amplifies 1-1145 of AF416619 plus FLAG sequence) and hPRL- $\Delta 7 / 11$ (amplifies 18-821 of AF492470 plus FLAG sequence) or SF1b-FLAG3P (5'-GC GGGAATTGTGATTTATGGTGATGGTGTT TGTAGTGAGGGGTCACGTCGAACAGAT-3'; amplifies 1-881 bp of AF416618 plus FLAG coding sequence) for hPRLR-SFlb. These PCR products were digested with BamHI and EcoRI, purified and cloned into pEF4A or pEF6C (digested with BamHI and EcoRI) and sequence verified.

\section{Cell culture and transfection}

Chinese hamster ovary cells (CHO-Kl) were maintained in $\alpha$-MEM (Life Technologies) sup- plemented with 10\% fetal bovine serum (Life Technologies), penicillin $(100 \mathrm{U} / \mathrm{ml})$ and streptomycin $(100 \mu \mathrm{g} / \mathrm{ml}$; Life Technologies). Transfections were performed using Fugene (Roche Molecular Biochemicals, Indianapolis, IN, USA) at a ratio of $1 \mu \mathrm{g}$ DNA to 3-4 $\mu$ l Fugene. Transfection efficiencies were controlled by co-transfection with pEFlacZ or monitored by parallel transfection with pCMV-GFP. To examine PRLR signaling to the $\beta$-casein promoter, $\mathrm{CHO}-\mathrm{K} 1$ cells were plated in six-well dishes at $2 \cdot 1 \times 10^{5}$ cells/well the day before transfection. Each well was transfected with $1.5 \mu \mathrm{g}$ PRLR and/or empty vector (pEF6G) DNA, $0.5 \mu \mathrm{g} \beta$ casCAT DNA and $0.2 \mu \mathrm{g}$ pEFlacZ DNA. Cells were transfected for $24 \mathrm{~h}$ then the media changed to $\alpha$-MEM supplemented with ITS + 1(BD Biosciences, Palo Alto, CA, USA), penicillin, streptomycin and dexamethasone $(1 \mu \mathrm{M}$; Sigma, St Louis, MO, USA), with or without ovine PRL (oPRL; $400 \mathrm{ng} / \mathrm{ml}$; Sigma). After $48 \mathrm{~h}$, the cells were scraped into $1 \times$ Reporter Lysis Buffer (Promega, Madison, WI, USA) and the supernatant stored at $-80{ }^{\circ} \mathrm{C}$ until assayed. For live cell binding assays, CHO-K1 cells were plated in 12-well dishes at $1 \times 10^{5}$ cells per well the day before transfection, and then transfected for $24 \mathrm{~h}$ using $4 \cdot 5 \mu \mathrm{l}$ Fugene plus 0.5 or $1.5 \mu \mathrm{g}$ DNA per well. The cells were then incubated in serum-free medium $(\alpha$-MEM, ITS +1 , penicillin and streptomycin) for a further 16-24 $\mathrm{h}$ and were confluent at the time of the binding assay. When hPRLR-LF was transfected with various ratios of either hPRLR-SFla or hPRLR-SF1b, a total of $1 \mu \mathrm{g}$ DNA or $1.5 \mu \mathrm{g}$ DNA was used respectively with $4 \cdot 5 \mu$ l Fugene.

For secreted protein binding assays, CHO-K1 cells were plated in six-well dishes at $2 \cdot 4 \times 10^{5}$ cells per well the day before transfection, and then transfected for $24 \mathrm{~h}$ using $2 \mu \mathrm{g}$ DNA per well. The cells were then incubated in serum-free medium $(\alpha$-MEM, ITS +1 , penicillin and streptomycin) for a further $24 \mathrm{~h}$.

For immunocytochemistry, CHO-K1 cells were plated onto glass chamber slides (Nalge Nunc International, Rochester, NY, USA) and transfected for $72 \mathrm{~h}$, prior to immunostaining.

\section{Reporter gene assays}

Cell lysates were assayed for CAT activity using $\left[{ }^{14} \mathrm{C}\right]$ chloramphenicol $(0 \cdot 025 \mathrm{mCi} / \mathrm{ml}$; Amersham Pharmacia Biotech, Piscataway, NJ, USA) and the 
CAT Enzyme Assay System (Promega) at $37{ }^{\circ} \mathrm{C}$ for $2 \mathrm{~h}$. The butyrylated $\left[{ }^{14} \mathrm{C}\right]$ chloramphenicol was extracted with $300 \mu \mathrm{l}$ xylene, back extracted once with $100 \mu \mathrm{l} 0 \cdot 25 \mathrm{M}$ Tris-HCl (pH 8), then $200 \mu \mathrm{l}$ of the organic phase was counted using Ecoscint A (National Diagnostics, Atlanta, GA, USA) in an LS6000IC scintillation counter (Beckman, Fullerton, CA, USA). $\beta$-Galactosidase activity was measured using a 96-well colorimetric assay ( $\beta$-galactosidase Enzyme Assay System; Promega) and the absorbance determined using an ELx800UV microtiter plate reader (Bio-Tek Instruments Inc, Winoaski, VT, USA).

\section{Binding assays}

Live cell binding assays were performed in triplicate or quadruplicate on transiently transfected live CHO-K1 cells approximately $40 \mathrm{~h}$ after transfection. Cells were washed once with PBS ( $\mathrm{pH}$ $7 \cdot 4)$ then were incubated in $0.5 \mathrm{ml}$ binding medium $(\alpha$-MEM, $0 \cdot 1 \%$ BSA, $12.5 \mathrm{mM}$ Hepes, pH 7.3) supplemented with ${ }^{125}$ I-human growth hormone (hGH) $\left(10^{5}\right.$ c.p.m. at $2200 \mathrm{Ci} / \mathrm{mmol}$; Amersham Pharmacia Biotech) in the presence of various concentrations of unlabeled oPRL (0-3000 ng/ml) for $4 \mathrm{~h}$ at room temperature. Cells were then washed with PBS and lysed with 3\% SDS. Bound ${ }^{125} \mathrm{I}-\mathrm{hGH}$ was counted in a Packard Multi-Prias $\gamma$-counter (Perkin Elmer). Competitive binding data for the various hPRLR isoforms were analyzed using GraphPad Prism3 (GraphPad Software Inc., San Diego, CA, USA).

Secreted protein binding assays were performed $48 \mathrm{~h}$ after transfection. Cells were incubated overnight in serum-free media containing ${ }^{125} \mathrm{I}$ hGH (200 000 c.p.m./ml) with or without $10 \mu \mathrm{g}$ oPRL. Media $(0.8 \mathrm{ml})$ was immunoprecipitated in duplicate using $\alpha$-FLAG M2 mouse monoclonal antibody (mAb) affinity gel (Sigma) and bound ${ }^{125}$ I-hGH was counted in a EG\&G Wallac 1272 Clinigamma $\gamma$-counter (Perkin Elmer).

\section{Immunoprecipitation and Western analysis}

Transfected CHO-K1 cells were harvested and sonicated in homogenization buffer $(25 \mathrm{mM}$ Tris $\mathrm{pH} 75,2 \mathrm{mM} \quad \mathrm{MgCl}_{2}, 1 \mathrm{mM}$ EDTA, $1 \mathrm{mM}$ dithiothreitol, $1 \mu \mathrm{M}$ leupeptin, $1 \mu \mathrm{M}$ pepstatin $\mathrm{A}$, $1 \mu \mathrm{g} / \mathrm{ml}$ aprotinin, $10 \mu \mathrm{g} / \mathrm{ml}$ trypsin inhibitor, $20 \mu \mathrm{g} / \mathrm{ml}$ phenylmethylsulfonyl fluoride, $1 \%$ Triton
$\mathrm{X}-100)$. Total protein (2 $\mathrm{mg})$ was subjected to immunoprecipitation with $40 \mu \mathrm{l} \quad \alpha$-FLAG M2 mouse mAb affinity gel (Sigma)

Medium was harvested from transfected CHO-K1 cells and $0 \cdot 8-1 \mathrm{ml}$ was immunoprecipitated using $20 \mu \mathrm{l}(10 \mu \mathrm{l}$ packed gel volume) $\alpha$ FLAG M2 mouse mAb affinity gel as per the manufacturer's instructions.

From total cell lysate, $80-100 \mu \mathrm{g}$ protein was subjected to $10 \%$ SDS-PAGE. Proteins were transferred to Hybond nitrocellulose EC membrane (Amersham Pharmacia Biotech) and probed with either mouse $\alpha$-FLAG M2 Monoclonal IgG Antibody (Sigma), followed by horseradish peroxidase (HRP)-conjugated sheep anti-mouse secondary antibody, or mouse $\alpha$-FLAG M2 Monoclonal IgG Antibody-HRP conjugate (Sigma). Immunoreactivity was detected using enhanced chemiluminescence (ECL+plus; Amersham Pharmacia Biotech). Molecular size determinations were made using MagicMark Western Standard (Invitrogen).

\section{Fluorescent immunocytochemistry}

Cells were washed five times with PBS, fixed in $1 \%$

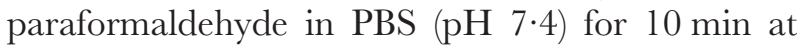
RT and then permeabilized with $0 \cdot 2 \%$ Triton-X 100, 1\% horse serum in PBS for 5 min on ice. Cells were then incubated for $30 \mathrm{~min}$ with mouse a-FLAG M2 Monoclonal IgG Antibody-HRP conjugate (1:100), followed by $30 \mathrm{~min}$ with Cy3-conjugated AffiniPure Rabbit Anti-HRP 1:250; Jackson ImmunoResearch Laboratories, Inc., West Grove, PA, USA). Slides were mounted with DAPI antifade media (Molecular Probes, Inc., Eugene, OR, USA).

\section{Northern analysis}

Total RNA was extracted from transiently transfected CHO-K1 cells using Trizol (Life Technologies). Following DNase treatment, total RNA $(10 \mu \mathrm{g})$ was subjected to Northern analysis. The blot was probed with a $716 \mathrm{bp}$ fragment from the extracellular domain generated by PGR using $0.2 \mu \mathrm{M}$ of the forward (PRLR 5'; 5'AAGGAAACATTCACGTGCTG-3') and reverse (PRLR 3'; 5'-AATCCTTTTATTTTTGGCGC$\left.3^{\prime}\right)$ primers and an annealing temperature of $54{ }^{\circ} \mathrm{C}$. The probe was labeled with $\left[\alpha-{ }^{32} \mathrm{P}\right] \mathrm{dCTP}$ using RediprimeII (Amersham Pharmacia Biotech) and 
Table 1 Sequences, annealing temperature and expected amplicon sizes for primer pairs used to detect expression of $\mathrm{hPRLR}$ isoforms and housekeeping genes

\begin{tabular}{|c|c|c|c|}
\hline & $\begin{array}{l}\text { Amplicon } \\
\text { size (bp) }\end{array}$ & $\begin{array}{l}\text { Annealing temperature } \\
\left({ }^{\circ} \mathrm{C}\right)\end{array}$ & $5^{\prime}$ Primer $\left(5^{\prime}-3^{\prime}\right)$ and $3^{\prime}$ primer $\left(5^{\prime}-3^{\prime}\right)$ \\
\hline \multicolumn{4}{|l|}{ Gene } \\
\hline hPRLR-SF1a & 795 & 60 & CCAGCGACCTTCATTCAGATAC \\
\hline hPRLR-SF1b & 641 & 60 & GCCACATCCTTCACAAACACC \\
\hline$\Delta 7 / 11$ & 471 & 60 & \\
\hline & & & TGGGAGATCCATTTTGCTGGGC \\
\hline hPRLR-LF & 1487 & 62 & $\begin{array}{l}\text { GCTGGAGAAAGAGGCAAGTGG } \\
\text { TTCACCATGAATGATACAACCG }\end{array}$ \\
\hline hPRLR-LF & 398 & 58 & $\begin{array}{l}\text { TCAGACAAAAGGGAAGGGC } \\
\text { GAGAATCCTGAAACAACCCACACC }\end{array}$ \\
\hline hPRLR-LF & 398 & 60 & $\begin{array}{l}\text { TTGACCTTGTGAATCTCCACATAATCC } \\
\text { GATGAGAAGGACCCACGGCGTCTGTTCG }\end{array}$ \\
\hline Ribosomal protein S9 & 431 & 68 & $\begin{array}{l}\text { GAGACAATCCAGCAGCCCAGGAGGGACA } \\
\text { TGAAGGTCGGAGTCAACGGATTTGGT }\end{array}$ \\
\hline hGAPDH & 983 & 68 & $\begin{array}{l}\text { CATGTGGGCCATGAGGTCCACCAC } \\
\text { TGAAGGTCGGTGTGAACGGATTTGGC }\end{array}$ \\
\hline Mouse GAPDH & 983 & 60 & $\begin{array}{l}\text { CATGTAGGCCATGAGGTCCACCAC } \\
\text { ATCTGGCACCACACCTTCTACAATGAGCTGCG }\end{array}$ \\
\hline$\beta$-Actin & 838 & 60 & CGTCATACTCCTGCTTGCTGATCCACATCTGC \\
\hline
\end{tabular}

hybridized overnight with the blot at $65^{\circ} \mathrm{C}$ in Church buffer (Church \& Gilbert 1984). Following hybridization the blot was washed four times with $0.5 \times \mathrm{SSC}(0.15 \mathrm{M} \mathrm{NaCl} / 0.015 \mathrm{M}$ trisodium citrate $\mathrm{pH} 7 \cdot 6$ ), $0 \cdot 1 \% \mathrm{SDS}$ at $65^{\circ} \mathrm{C}$, and subjected to autoradiography.

\section{RT-PCR analysis of PRLR expression}

Two collections of pooled tissue cDNA from 14- to 76 -year-old humans $(0 \cdot 2 \mathrm{ng} / \mu \mathrm{l}$; Clontech $)$ were used as the templates for PGR ( $5 \mu$ l per reaction). All samples were from both males and females except for liver (from males), lung (from females) and sex-specific tissues. Total RNA from a series of cancerous and normal human breast cell lines, and ten matched normal and cancerous breast samples, was extracted using Trizol and $1 \mu \mathrm{g}$ used for RT reactions. Total RNA (1 $\mu \mathrm{g})$ from 26 breast cancer samples, nine matched normal and cancer colon samples, and three additional tumor samples was also used for RT reactions. PGR was performed on $2 \cdot 5 \mu \mathrm{l}$ RT product using PCR Master Mix (Roche) with $0 \cdot 2-0 \cdot 4 \mu \mathrm{M}$ of each primer. The sequence of primers used to detect hPRLR-SFla, hPRLR-SF1b and $\Delta 7 / 11$ after 40 rounds of amplification are presented in Table 1. Primer sequences used to amplify hPRLR-LF with 35 cycles of PCR are given in Table 1. The sequence of the various short PRLR isoform products was confirmed after they were cloned into pCR2.1 (Invitrogen). The integrity of RNA was determined using primers for either human glyceraldehyde-3-phosphate dehydrogenase (hGAPDH; 24-27 cycles; Clontech; Table 1), ribosomal protein S9 (23 cycles; Clontech; Table 1) or $\beta$-actin (25 cycles; Clontech; Table 1). The integrity of RNA from CHO-K1 cells was tested using mouse GAPDH primers (22 cycles; Clontech; Table 1). For all PGR analyses the number of cycles used was selected to provide the full range of amplicon intensity across a linear range for the group of samples tested. The intensity of agarose gel-resolved PCR products was quantified using NIH Image and expressed relative to the level of the corresponding housekeeping gene.

\section{Statistics}

Levels of CAT activity following treatment with and without PRL were compared by Student's $t$-test. One-way ANOVA was used to compare total specific binding for the different PRLR isoforms. Specific binding by $\Delta 7 / 11$ in media was analyzed using Student's $t$-test. 


\begin{abstract}
A
GTGACCCCTTGATGTTGGGTGCCTCTCATTACAAAAATCTCAAATCTTACAGACCAAGAA AAATCTCAAGTCAAGGAAGACTTGCGGTGTTCACAAAGGCAACATTGACCACAGTCCAGT AGAGCTGAAGAGCATATACCAGAATTCAGGAACTCAACATTTTCTCCCCTCTGTCCAACC ACAGGACAGACTGTGCACCCCAGGGAGATGCTGTGTGTCCACTGGCCTCACTGACTTGGA TTACTCCTGCAGCACGTGACCAGCCAGCTCATATGATCACTCCCTACTGCCCCCAAAGCA GAATTGACTGGGAGCTGGAAACCCACACAAAAAGGGACAATTATATTGAATGTAACATAC TCCCTCTGCTTACCTAGTGCCTTCACCTCCTATGGGCATTTGGAGTAAAAGGTTGTTATG CAGGTGTTTGTGAAGGATGTGGCCAAGTCAGTTGTCTCCCTTACAGGGTGACCCAAGATT AATGATATCTACCCATCCCCAGTCCCTCGACCCCCTAGTTGCAATCAGCTTTGTCACTGT CCCCCTTAGGCACTGCCATGTAAAGCACGTGGTCCCCCATTCTGAAGCAGTGGGAAACCT AGAAGAGATGTACTCTTCGCAACCTGGTTGGATCTIAAAAACATGGTTCTAAC (A) 18
\end{abstract}

60

120

180

240

300

360

420

480

540

600

653

B

LF KGYSMVTCTFPPVPGAKIKGFDAHLLEKGKSEELLSALGCODFPPTSDYEDLIVEYLEVD IF KGYSMVTCIEPPVPGP KIKGFDAHLLEKGKSEELLSALGCQDEPPTSDYEDLIVEYLEVD SF1a KGYSMVTCIFPPVPGEKIKGEDAHLLEKGKSEELLSALGCQDFPPTSDYEDLIVEYLEVD SF1b KGYSMVTCLFPPVPGBKIKGFDAHLLEVTP

318 318 318 288

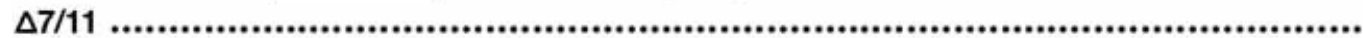
228

\begin{tabular}{l|l} 
LF & DSEDQH TSVHSKEHPSQGMKPTYLDPDTDSGRGSCDSPSLLSEKCEEPQANPSTEYDPE \\
IF & DSEDQHLMSVHSKEHPSQEREOROAOEARDS \\
SF1a DSEDQHLMSVHSKEHPSQGDPLMLGASHYKNLKSYRPRKISSOGRLAVETKATLTTVO
\end{tabular}

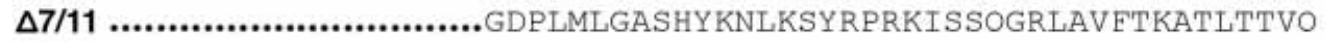

378 349 376 268

LF VIEKPENPETTHTWDPQCISMEGKIPYFHAGGSKCSTWPLPQPSQHNPRSSYHNITDVCE 438

LF LAVGPAGAPATLLNEAGKDALKSSQTIKSREEGKATQQREVESFHSETDQDTPWLLPQEK LF TPEGSAKPLDYVEIHKVNKDGALSLLPKQRENSGKPKKPGTPENNKEYAKVSGVMDNNIL LF VLVPDPHAKNVACEEESAKEAPPSLEONOAEKALANETATSSKCRLOLGGLDYLDPACFT 558

LF HSEH

618

622

Figure 1 Exon 11 sequence and derived amino acid sequences of two short hPRLR isoforms and one soluble isoform. (A) Nucleotide sequence of exon 11. The polyadenylation signal is boxed. (B) Amino acid sequence alignment of the intracellular domains of hPRLR long form (LF), intermediate form (IF), short form 1a (SF1a) and short form 1b (SF1b) with corresponding exon 11-encoded amino acid sequence from the $\Delta 7 / 11$ isoform. The proline-rich box 1 (proximal to the transmembrane domain) and the more distal box 2 are boxed. The intracellular amino acids in SF1a, SF1b and IF that differ compared with LF are underlined.

\section{Results}

\section{Cloning of five hPRLR splice variants}

An exon 11 of the hPRLR gene was identified by $3^{\prime}$ RACE from human ovary cDNA and subsequent comparison with the draft human genome sequence (http://www.ncbi.nlm.nih.gov/genome/ guide/human/). The clone contained sequence from exon 9 of the hPRLR-LF that spliced to exon 11 (Fig. 1). Using RT-PCR, we subsequently identified five alternative splice variants containing exon 11 sequence (Fig. 2). For two of these, hPRLR-SFla (GenBank Accession AF416619) and hPRLR-SF1b (GenBank Accession AF416618), 


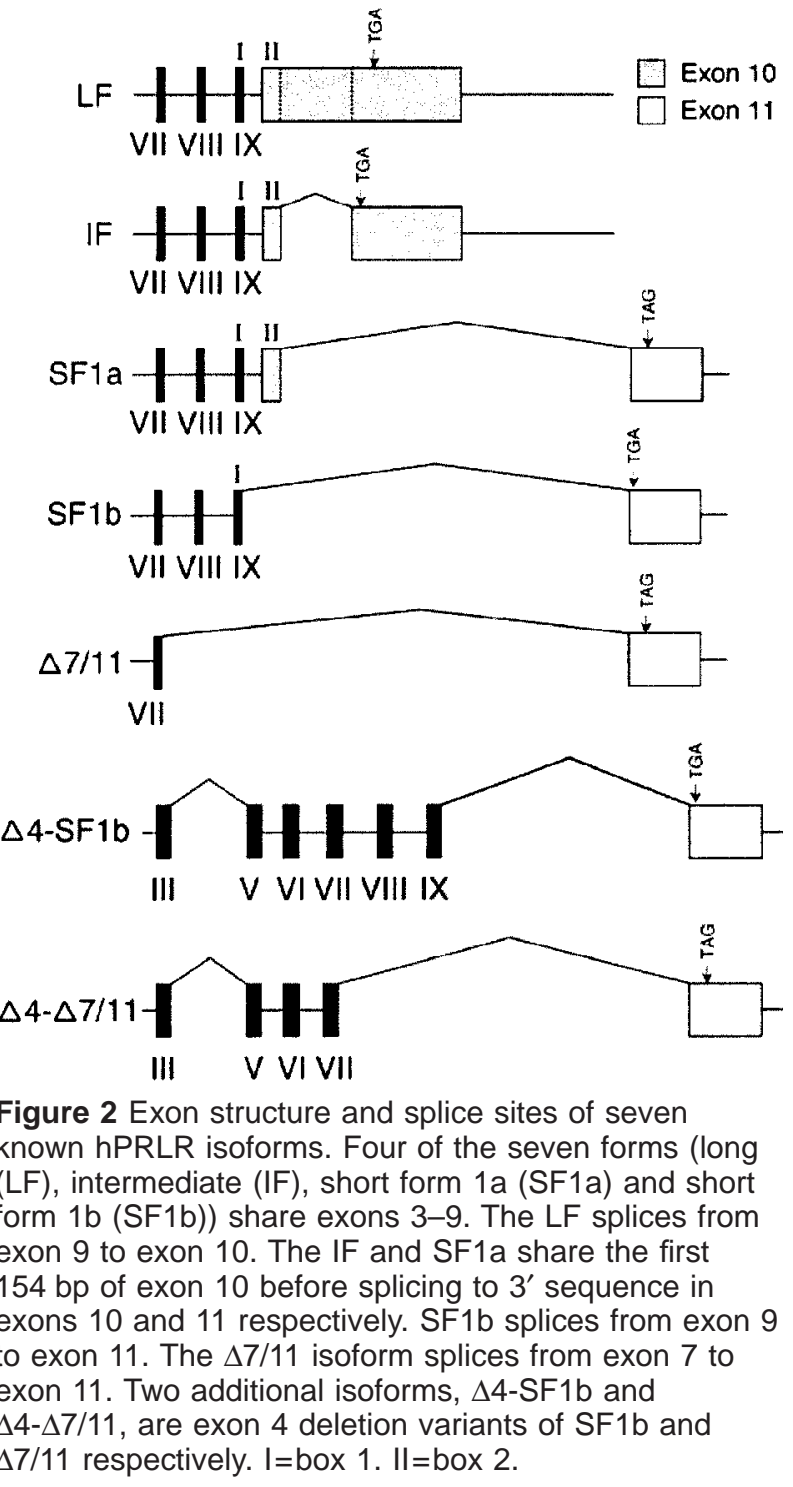

full-length cDNA possessing exons 3-11 was cloned from placenta. A full-length cDNA for a third, soluble form $(\Delta 7 / 11$; Genbank Accession AF492470) was cloned from breast cancer RNA. The $\Delta 7 / 11$ isoform did not contain a transmembrane domain as determined by TMpred (http: //www.ch.embnet.org/software/TMPRED_form. html) and was predicted to be a binding protein. Subsequent analysis of breast cancer RNA revealed another two splice variants that lacked exon 4 in the hPRLRSF1b $(\Delta 4-S F 1 b$; GenBank Accession AF512796) and $\Delta 7 / 11(\Delta 4-\Delta 7 / 11 ;$ GenBank Accession AF493068) sequences. These five variants were alternatively spliced from a single
PRLR gene (Fig. 2) located on chromosome 5. Examination of the human genome map using NCBI Blast (http://www.ncbi.nlm.nih.gov/ genome/seq/HsBlast.html) revealed that exon 11 is separated from exon 10 by an intron of $15 \cdot 1 \mathrm{~kb}$, and is $18.8 \mathrm{~kb}$ downstream of exon 9 and $20.7 \mathrm{~kb}$ downstream of exon 7 . The full-length coding sequence and 3'-UTR of hPRLR-SFla comprised exons 3 to 9, 154 bp of exon 10 (as present in both the hPRLR-LF and the IF; Kline et al. 1999), then $653 \mathrm{bp}$ of exon 11 (Figs 1 and 2). The full-length hPRLR-SF1b coding sequence and 3 '-UTR comprised exons 3-9 followed by 653 bp of exon 11 (Figs 1 and 2). The full-length $\Delta 7 / 11$ isoform comprised exons 3-7 then exon 11 in the same reading frame as hPRLR-SFla. The splicing sites follow the AG/GT rule of Mount (1982) and there was a non-consensus polyadenylation site of TAAAAA in exon $11,13 \mathrm{bp}$ upstream of the poly (A)18 tail.The sequences of hPRLR-SFla, hPRLRSF $1 \mathrm{~b}$ and $\Delta 7 / 11$ encode 376 aa, 288 aa and 268 aa precursor proteins. These proteins share homology with both hPRLR-LF and IF for the first 336 aa, 285 aa and 228 aa respectively (Fig. 1). The intracellular domain of hPRLR-SFla contains both box 1 and box 2 motifs characteristic of the cytokine receptor superfamily (Bole-Feysot et al. 1998) whereas hPRLR-SF1b contains only box 1 , and $\Delta 7 / 11$ lacks both. The $\Delta 4-\Delta 7 / 11$ and $\Delta 4-S F 1 b$ splice variants both encode either a truncated $\mathrm{N}$-terminal 34 aa peptide (including the signal peptide), or C-terminal proteins that are identical to $\Delta 7 / 11$ and SF1b respectively, but lack the signal peptide (24 aa) and first 47 aa of the extracellular domain, which would probably abolish their ability to bind PRL.

\section{Differential lactogen binding by hPRLR isoforms}

To determine the binding characteristics of the two transmembrane-containing PRLR isoforms (hPRLR-SFla and hPRLR-SF1b), we transiently transfected CHO-K1 cells with these PRLR expression constructs prior to incubation with ${ }^{125}$ I-hGH. CHO-K1 cells transfected with pEF6C alone did not specifically bind ${ }^{125} \mathrm{I}-\mathrm{hGH}$ (data not shown). Likewise they did not express PRLR mRNA as determined by RT-PGR (data not shown). Transfection of CHO-K1 cells 
with expression vectors encoding hPRLR-SFla, hPRLR-SF1b or hPRLR-LF resulted in similar mRNA and protein expression for all three isoforms as determined by Northern analysis and Western analysis (Fig. 3). The size of mRNA transcripts for hPRLR-SFla, hPRLR-SFlb and hPRLR-LF concurred with the predicted sizes of 2, 1.9 and $3.5 \mathrm{~kb}$ respectively. Two PRLR mRNA transcripts of approximately 9 and $3.5 \mathrm{~kb}$ were detected in T47D cells, similar to previous results using Northern analysis of hPRLR-LF expression (Boutin et al. 1989). Western analysis of FLAGtagged protein products indicated that SFlaFLAG, SF1b-FLAG and LF-FLAG encoded translation products of approximately 57, 38 and $93 \mathrm{kDa}$ respectively (Fig. 3B). The predicted sizes of mature SF1a-FLAG and SF1b-FLAG are 41 and $31 \mathrm{kDa}$ respectively (http://www.expasy.ch/tools/ pi_tool.html). The hPRLR-LF specifically bound hGH that was competitively displaced by oPRL $\left(K_{\mathrm{m}}=3.3 \mathrm{nM} ; 95 \%\right.$ confidence interval $(\mathrm{CI})=2 \cdot 0$ $5.4 \mathrm{nM}$; Fig. 4A). The hPRLR-SFla bound a small but specific amount of hGH when $1.5 \mu \mathrm{g}$, but not $0.5 \mu \mathrm{g}$, of receptor was used in transfection studies (Fig. 4B). The binding affinity for hPRLR-SFla could not be accurately determined due to the low specific binding (Fig. 4A) although our data suggest it had an affinity for hGH similar to that for hPRLR-SF1b or hPRLR-LF. The hPRLR-SF1b had 3-fold higher total specific binding of hGH than did the hPRLR-LF (Fig. 4B) while binding the ligand with a similar affinity $\left(K_{\mathrm{m}}=3.4 \mathrm{nM} ; 95 \%\right.$ $\mathrm{CI}=2 \cdot 3-5 \cdot 2 \mathrm{nM}$; Fig. $4 \mathrm{~A})$. The total specific binding capacity of hPRLR-SF1b was $2 \cdot 4$-fold greater than for hPRLR-LF while the specific binding capacity of hPRLR-SFla was 8-fold lower than for hPRLR-LF. When both hPRLR-LF and hPRLR-SF1b were transfected into CHO-K1 cells at a 1:1 mass ratio, the affinity for hGH was decreased compared with either hPRLR-LF or hPRLR-SF1b alone $\left(K_{\mathrm{m}}=9 \mathrm{nM} ; 95 \% \quad \mathrm{CI}=4 \cdot 4\right.$ $18 \mathrm{nM}$; Fig. 4A). When different ratios of hPRLR-LF to hPRLR-SFlb were used, addition of increasing amounts of hPRLR-SF1b to a constant level of hPRLR-LF produced a non-additive increase in specific binding (Fig. 4C). When different ratios of hPRLR-LF to hPRLR-SFla were used, addition of increasing amounts of hPRLRSFla to a constant level of hPRLR-LF produced a decrease in specific binding (Fig. 4D). Similarly, the addition of increasing levels of hPRLR-SFla to a
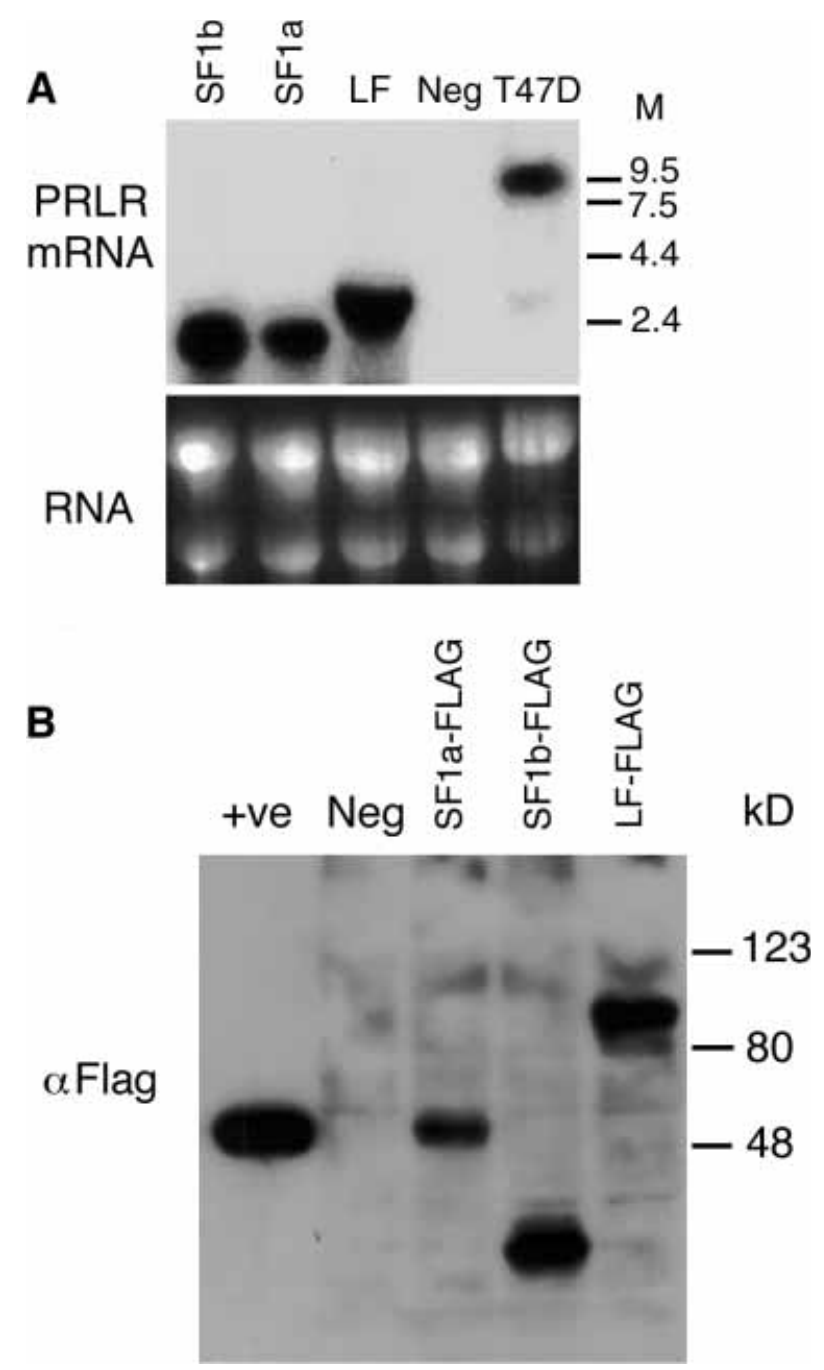

Figure 3 Expression of hPRLR long form (LF), short form 1a (SF1a) and short form 1b (SF1b) mRNA in transiently transfected $\mathrm{CHO}-\mathrm{K} 1$ cells. Cells were transfected for $24 \mathrm{~h}$, the media replaced with serum-free media and the cells harvested for RNA or protein extraction $40 \mathrm{~h}$ later. The negative control (Neg) is cells transfected with pEF6C. (A) Expression of hPRLR mRNAs as determined by Northern analysis of total RNA $(10 \mu \mathrm{g})$. Cells transfected with SF1a, SF1b or LF expression constructs expressed mRNA transcripts of the expected sizes. As a positive control, RNA from T47D cells was analyzed for PRLR mRNA. Equivalence of loading is demonstrated by the intensity of $18 \mathrm{~S}$ and $28 \mathrm{~S}$ ribosomal RNA bands. Migration of the RNA ladder (M) is indicated. (B) Western blot analysis of SF1a-FLAG, SF1b-FLAG and LF-FLAG proteins in transfected $\mathrm{CHO}-\mathrm{K} 1$ cells probed with anti-FLAG antibody. Total cell lysates ( $80 \mu \mathrm{g}$ protein) were loaded on the gel. The positive control (+ve) was $100 \mathrm{ng}$ of FLAG bacterial alkaline phosphatase protein. 

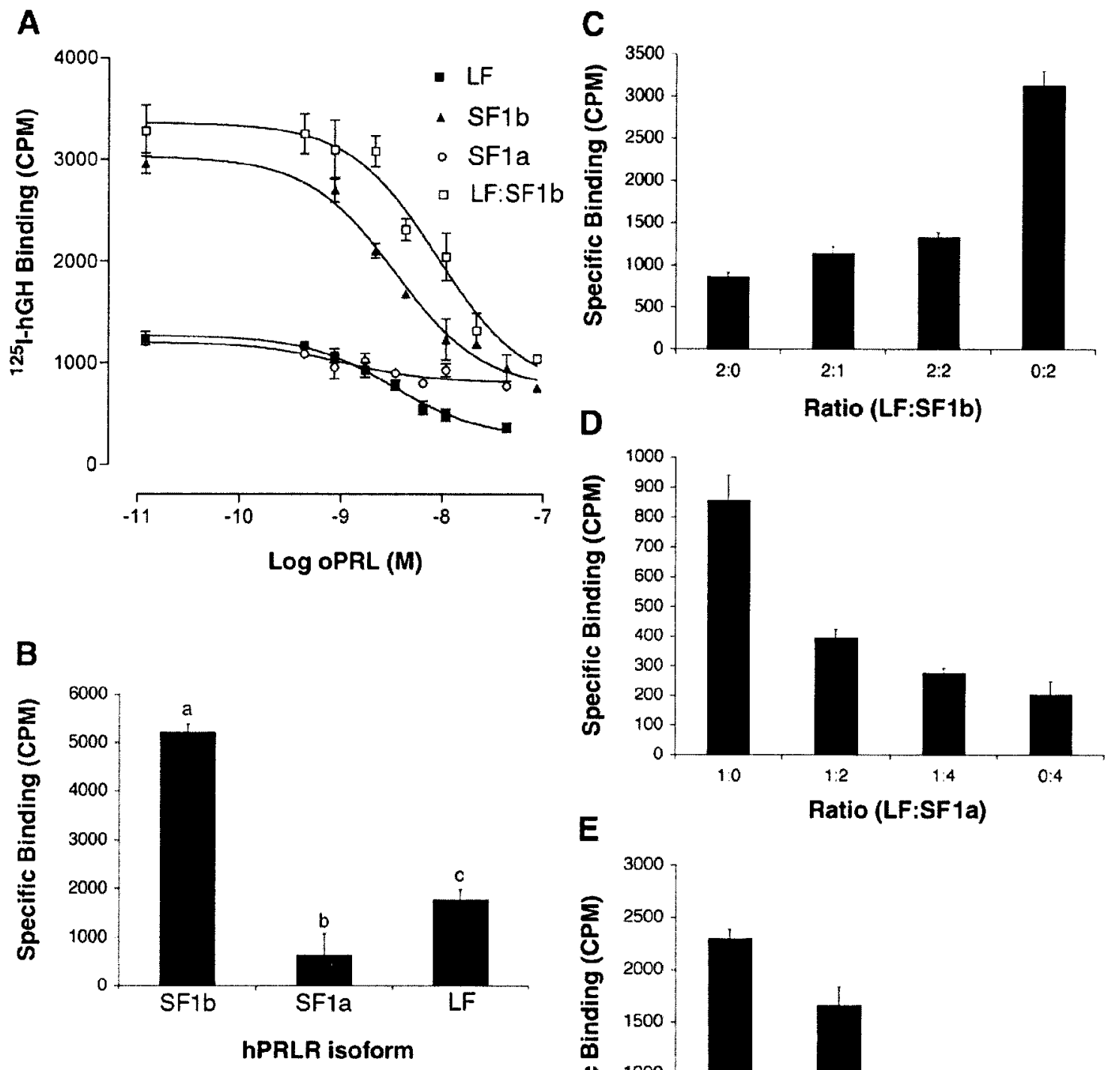

E

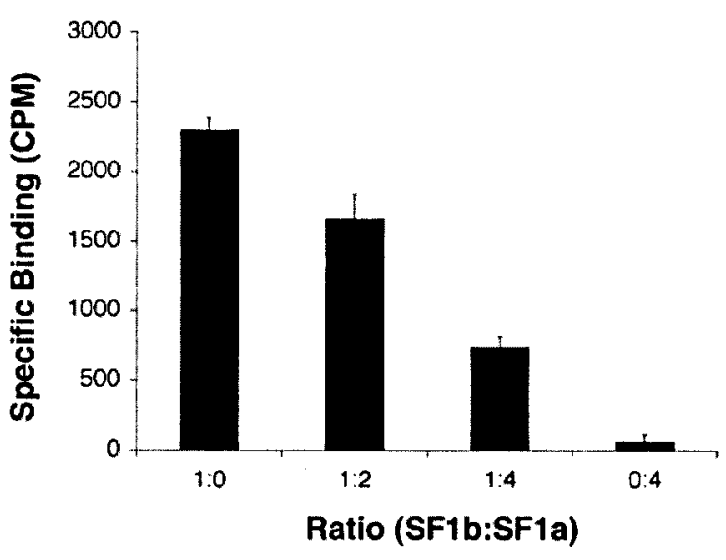

Figure 4 Ligand-binding competition curves for ${ }^{125} \mathrm{I}-\mathrm{hGH}$ using $\mathrm{CHO}-\mathrm{K} 1$ cells transiently transfected with various hPRLR isoforms. (A) Competition binding curves for hPRLR long form (LF), short form 1a (SF1a), short form $1 \mathrm{~b}$ (SF1b) and a 1:1 ratio of LF: SF1b showing the binding site competition of ${ }^{125}$ I-hGH using increasing amounts of unlabeled oPRL. The LF, SF1a and SF1b curves are representative of three independent experiments. (B) Total specific binding of ${ }^{125} \mathrm{I}-\mathrm{hGH}$ to $\mathrm{CHO}-\mathrm{K} 1$ cells transiently transfected with LF, SF1a or SF1b. Results are representative of three independent experiments. Means with different letters $(\mathrm{a}, \mathrm{b}, \mathrm{c})$ are significantly different $(P<0.0001)$. (C) Specific binding of ${ }^{125} \mathrm{I}-\mathrm{hGH}$ to CHO-K1 cells transiently transfected with a constant amount of LF $(0.5 \mu \mathrm{g})$ and various amounts of SF1b. (D) Specific binding of ${ }^{125} \mathrm{I}-\mathrm{hGH}$ to $\mathrm{CHO}-\mathrm{K} 1$ cells transiently transfected with a constant amount of LF $(0.3 \mu \mathrm{g})$ and various amounts of SF1a. (E) Specific binding of ${ }^{125} \mathrm{I}-\mathrm{hGH}$ to $\mathrm{CHO}-\mathrm{K} 1$ cells transiently transfected with a constant amount of SF1b $(0.3 \mu \mathrm{g})$ and various amounts of SF1a. All data are means \pm S.E. for triplicate or quadruplicate determinations. 

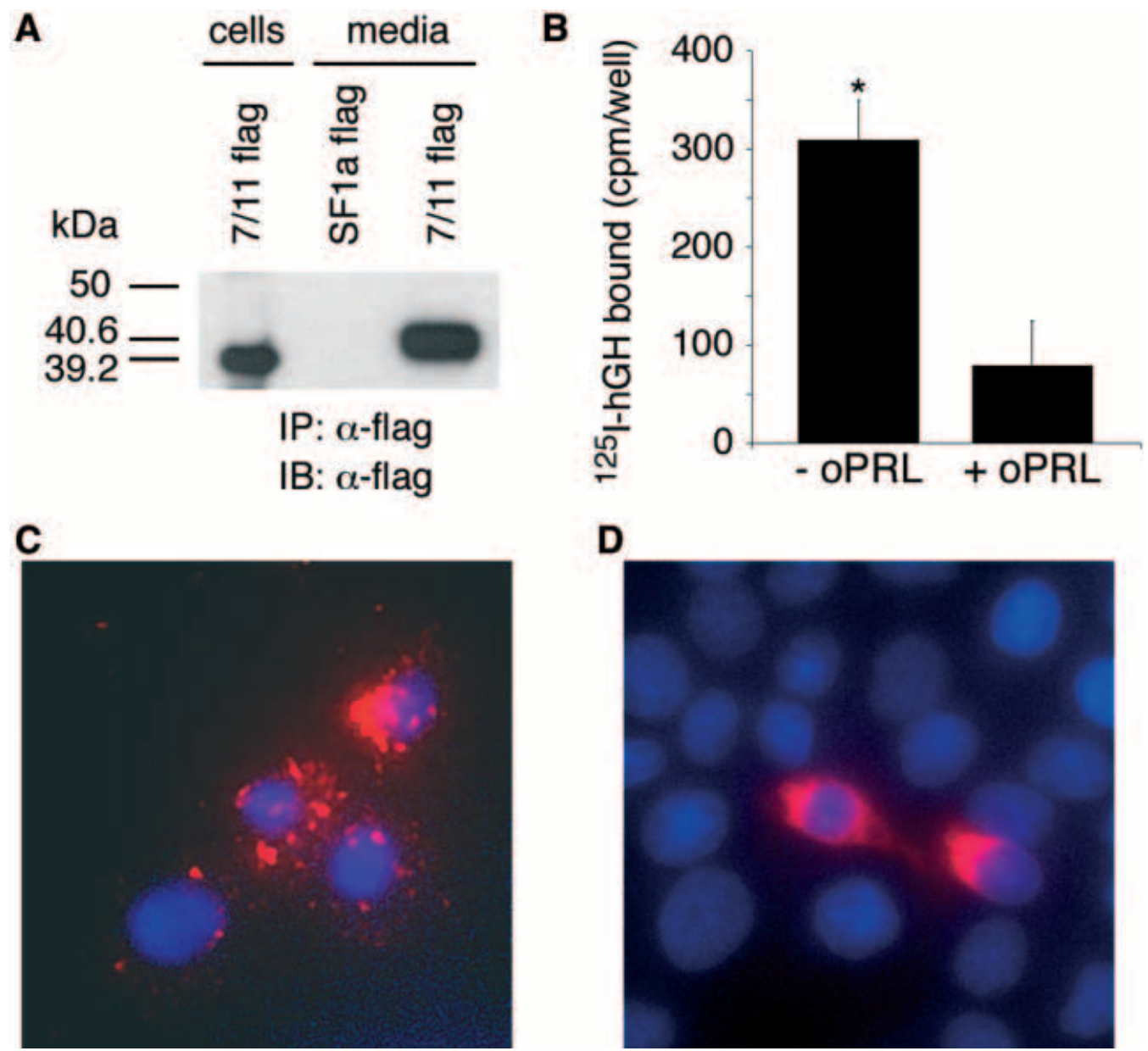

Figure $5 \Delta 7 / 11$ is a secreted isoform of the PRLR and specifically binds ${ }^{125} \mathrm{I}-\mathrm{hGH}$. (A) Media or cell lysates from CHO-K1 cells transfected with SF1a-FLAG or $\Delta 7 / 11-\mathrm{FLAG}$ were immunoprecipitated with $\alpha$-FLAG mAb. Immunoprecipitates were immunoblotted with $\alpha$-FLAG $\mathrm{mAb}$ conjugated to HRP. The equivalent of $250 \mu \mathrm{l}$ medium or $200 \mu \mathrm{g}$ cell proteins was loaded in each lane. (B) Medium from $\Delta 7 / 11$-FLAG- or LF-FLAG-transfected CHO-K1 cells incubated with ${ }^{125}$ I-hGH was immunoprecipitated with $\alpha$-FLAG mAb. No specific binding was obtained with media from cells transfected with LF-FLAG (data not shown). Radioactivity bound by $\Delta 7 / 11$-FLAG was normalized for non-specific binding of LF-FLAG media. ${ }^{*} P<0 \cdot 005$. Data are means \pm S.E. for quadruplicate determinations. (C, D) Fluorescent immunocytochemistry of (C) $\Delta 7 / 11-F L A G-$ and (D) LF-FLAG-transfected CHO-K1 cells. Red is Cy3 florescence. Blue is DAPI fluorescence. Magnification is $\times 400$.

constant level of hPRLR-SF1b also decreased specific binding (Fig. 4E).

\section{$\Delta 7 / 11$ is a secreted PRL-binding protein}

Since the sequence of $\Delta 7 / 11$ lacked a transmembrane domain but contained a complete extracellular binding domain, we hypothesized that the protein would be soluble, secreted extracellularly and would bind PRL. Western blot analysis demonstrated the presence of the $\Delta 7 / 11-\mathrm{FLAG}$ protein in both the media and cell lysates of 47/11-FLAG-transfected CHO-K1 cells (Fig. 5A). Conversely, the membrane-bound SFla-FLAG was not present in media (Fig. 5A), although it was clearly present in cell lysates (Fig. 3B). Interestingly, the $\Delta 7 / 11$-FLAG protein present in media was slightly larger than that in cells $(40 \cdot 6$ compared with $39 \cdot 2 \mathrm{kDa})$. The predicted size of the FLAG-tagged mature protein is $29 \cdot 1 \mathrm{kDa}$ (http:// 
www.expasy.ch/tools/pi_tool.html). We examined the ability of both secreted and intracellular $\Delta 7 / 11$ to bind ${ }^{125} \mathrm{I}-\mathrm{hGH}$ and found that cells containing $\Delta 7 / 11-\mathrm{FLAG}$ were unable to specifically bind ${ }^{125} \mathrm{I}-\mathrm{hGH}$ in live cell binding assays (data not shown). However, when the cells were cultured in the presence of ${ }^{125} \mathrm{I}-\mathrm{hGH}$, specifically bound hGH could be co-immunoprecipitated with $\Delta 7 / 11$ -
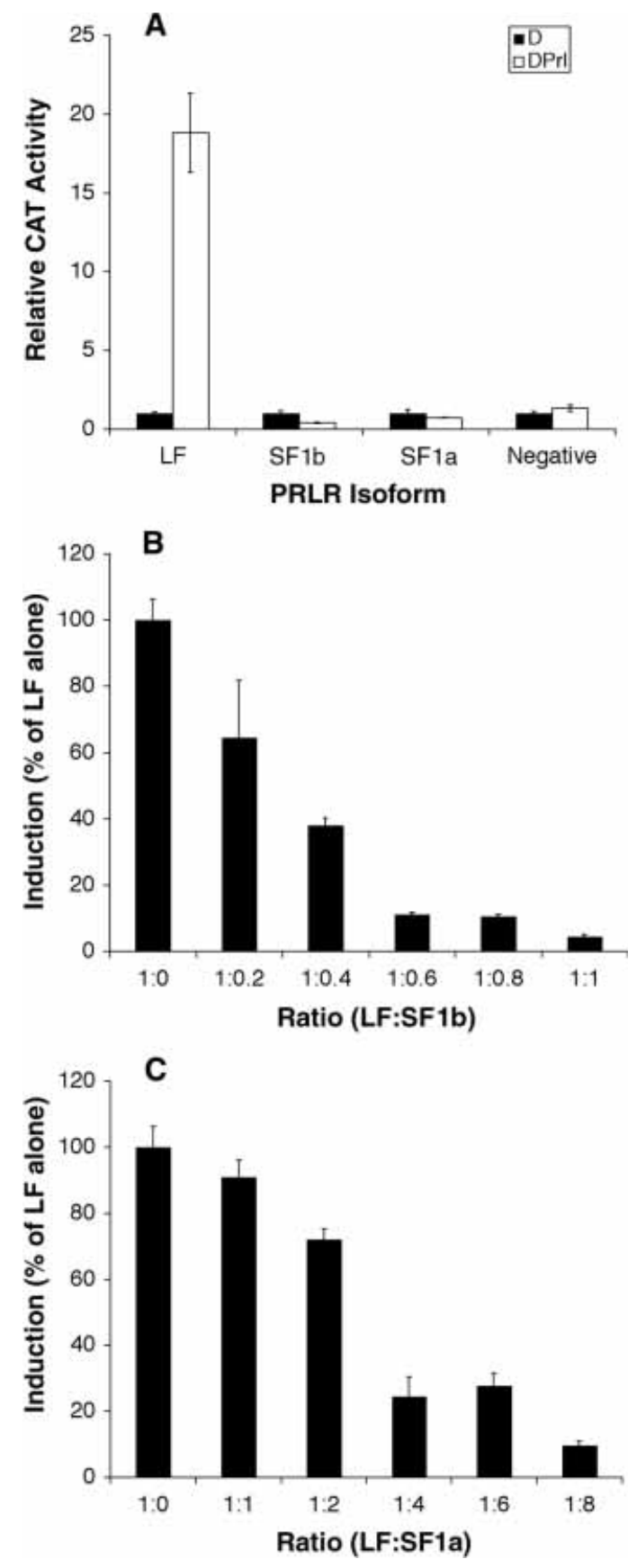

www.endocrinology.org
FLAG from the media, indicating that secreted $\Delta 7 / 11$ can bind ligand. Fluorescent immunocytochemistry of permeabilized CHO-K1 cells transfected with $\Delta 7 / 11-\mathrm{FLAG}$ revealed a punctate distribution within the cytoplasm, presumed to be vesicular (Fig. 5C). By comparison, LF-FLAG was cytoplasmic with perinuclear concentration (Fig. 5D), similar to previous observations (Genty et al. 1994, Perrot-Applanat et al. 1997).

\section{Transmembrane hPRLR isoforms are dominant-negatives for differentiation}

The ability of the two transmembrane-containing PRLR isoforms (SFla and SF1b) to transduce PRL-induced differentiation was tested using CHO-K1 cells co-transfected with a $\beta$ casCAT reporter and different PRLR constructs. Addition of PRL to CHO-K1 cells transfected with hPRLR-LF stimulated transcription from the $\beta$-casein promoter in the presence of insulin and dexamethasone $(\mathrm{P} \leq 0 \cdot 005$; Fig. 6A). In contrast, neither hPRLR-SFlb nor hPRLR-SFla transduced PRL-induced transcription from the $\beta$-casein promoter $(P>0.05$; Fig. 6A). We also tested whether these SFs could impart a dominantnegative effect on the differentiative signal transduced by the hPRLR-LF. Co-transfection of CHO-K1 cells with a constant amount of

Figure 6 Ability of short hPRLR isoforms to either transduce a differentiative signal or have dominant-negative effects on the hPRLR-LF. CHO-K1 cells were transiently transfected with $\beta$ casCAT, pEFLacZ and combinations of short form 1a (SF1a), short form 1b (SF1b), long form (LF) or pEF6C (Negative). The levels of CAT activity were normalized for $\beta$-galactosidase activity. (A) Transcription from the $\beta$-casein promoter in cells transfected with the various PRLR isoform constructs after treatment with either dexamethasone (D) alone or D plus PRL (DPrl). Results are representative of five independent experiments. (B, C) Various amounts of SF1a and SF1b were co-transfected with a constant amount of LF DNA. The total amount of DNA was held constant by adjusting the amount of pEF6C (empty vector) DNA. Ratios are mass ratios of transfected DNA. Each set of results was combined from two experiments and are representative of five independent experiments. (B) SF1b has a strong dominant-negative effect against LF-transduced PRL-stimulation of the $\beta$-casein promoter. (C) SF1a has a weak dominant-negative function against the LF-transduced PRL-stimulation of the $\beta$-casein promoter. Data are means \pm S.E. 


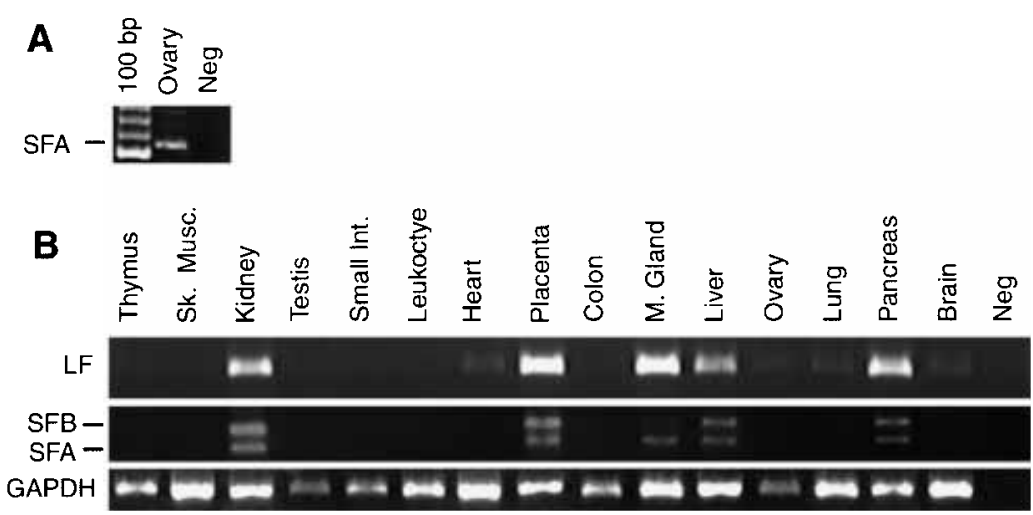

Figure 7 Expression of short form 1a (SF1a), short form 1b (SF1b), and long form (LF) mRNA in various normal human tissues as determined by RT-PCR. (A) Human ovary cDNA used for 3' RACE was subjected to PCR using primers that amplify both SF1a and SF1b. The PCR result was consistent over three independent amplifications. (B) Amplification of cDNA $(5 \mu \mathrm{l} ; 1 \mathrm{ng})$ by PCR in a $25 \mu \mathrm{l}$ reaction gave consistent results in three separate PCR reactions each performed on two panels of CDNA. The human breast tissue sample contained $\sim 2.5 \mathrm{ng}$ cDNA generated from poly A+RNA. hGAPDH was amplified by RT-PCR as an internal control. Sk. Musc. =skeletal muscle; Int. =intestine; M. Gland=mammary gland; Neg=negative control.

hPRLR-LF and increasing amounts of either hPRLR-SFla or hPRLR-SF1b revealed that hPRLR-SF1b is a strong dominant-negative to the differentiation signal transduced by the hPRLR-LF (Fig. 6B). While hPRLR-SFla only bound minimal amounts of lactogen (Fig. 4B), it did function as a dominant-negative to the differentiative function of the hPRLR-LF, albeit less effectively than hPRLRSF1b (Fig. 6G).

\section{Differential expression of PRLR isoforms in tissues and cell lines}

Expression of mRNA for the novel PRLR isoforms was examined in various human tissues by RT-PCR using primers in exons 7 and 11 that gave sequence-verified products of 795, 641 and $471 \mathrm{bp}$ for hPRLR-SFla, hPRLR-SF1b (and $\Delta 4$-SF1b) and $\Delta 7 / 11$ (and $\Delta 4-\Delta 7 / 11$ ) respectively. The exon 4 deletion variants that lack both a signal peptide and a complete extracellular domain were only expressed at low levels in certain samples of breast tumor tissue, as detected using primers in exons 3 and 11 . The significance of these splice variants is currently under investigation. The hPRLR-SF1b 3' RACE product was originally cloned from human ovary cDNA that expressed hPRLR-SF1b but not
-SFla (Fig. 7A). Expression of both hPRLR-SFla and hPRLR-SF1b mRNAs was detected in samples of human breast, placenta, kidney, liver and pancreas. These tissues also expressed hPRLR-LF whereas no expression of $\Delta 7 / 11$ was evident. By contrast, none of the exon 11-containing hPRLR isoforms was expressed in thymus, skeletal muscle, testis, small intestine, leukocytes, heart, colon, lung or brain (Fig. 7B). The absence of the SFs in two other samples of human ovary cDNA is noteworthy.

We also determined the expression of these three PRLR isoforms in normal breast and cancer cell lines. Both membrane-spanning isoforms (SFla and SF1b) were expressed in T47D, SKBR3, MDAMB453 and MDA-MB231 breast cancer cells (Fig. 8). In T47D cells the expression of mRNA for hPRLR-SFla was notably higher than for hPRLRSF1b. HS578 breast cancer cells only expressed mRNA for hPRLR-SF1a whereas BT20 breast cancer cells only expressed mRNA for hPRLRSF1b. No expression of the short PRLR isoforms was detected in MDA-MD435 breast cancer cells or the immortalized normal breast cell lines, A1N4 and MCF-10A. By contrast, hPRLR-LF mRNA was expressed by some cell lines that did not express mRNAs for the short PRLR isoforms. 


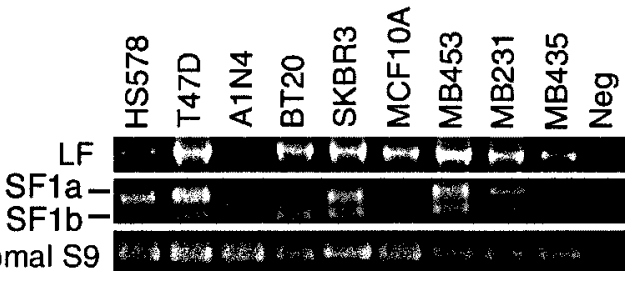

Ribosomal S9 8 Expression of hPRLR short form 1a (SF1a), Figure 8 Expression of hPRLR short form 1a short form $1 \mathrm{~b}(\mathrm{SF} 1 \mathrm{~b})$ and long form (LF) mRNA in
s. various human breast cell lines as determined by RT-PCR. Amplification of RT product gave consistent results in two separate RT-PCR reactions. Ribosomal protein S9 (ribosomal S9) was amplified by RT-PCR as an internal control. MB=MAD-MB; Neg=negative control.

Interestingly, no expression of the secreted $\Delta 7 / 11$-binding protein was detected in these various cell lines, perhaps reflective of the in vitro environment.

\section{Expression of hPRLR isoforms in breast and colon tumors}

We examined the expression of hPRLR-SFla, hPRLR-SF $1 b, \Delta 7 / 11$ and hPRLR-LF mRNAs in breast cancer tissue from 26 patients (Fig. 9A). Expression of hPRLR-LF was detected in all but one sample of normal breast or breast tumor while expression of one or more SFs was detected in all but three breast tumors and three samples of normal breast. In matched tissues, expression of $\Delta 7 / 11 \mathrm{mRNA}$ was evident in three normal and three cancerous breast samples (Fig. 9B).

Given these findings and the candidate role for PRL in colon cancer, we examined PRLR isoform expression in matched normal and tumor colon samples (Fig. 9G). Variable expression of hPRLRLF, hPRLR-SF $1 \mathrm{a}$ and hPRLR-SF1b was detected in matched normal and tumor samples. Expression of $\Delta 7 / 11 \mathrm{mRNA}$ was found in three normal samples and two colon tumor samples.

\section{Discussion}

The present study describes the cloning of five hPRLR isoforms generated by alternative splicing of a single PRLR gene on human chromosome 5. These isoforms contain $3^{\prime}$ sequence from exon 11 that exists at a significant distance $(15 \mathrm{~kb})$ downstream of exon 10. Both hPRLR-SFla and
hPRLR-SF1b have a dominant-negative effect on the differentiation signal transduced by the hPRLR-LF, where hPRLR-SF1b is more effective than hPRLR-SFla. By contrast, the $\Delta 7 / 11$ isoform encodes a soluble PRL-binding protein. Furthermore, these SFs are differentially expressed in both normal and tumorous breast and colon tissue.

Autocrine PRL is involved in the growth of breast cancer cells (Glevenger et al. 1995, Ginsburg \& Vonderhaar 1995) and several studies have linked a function of autocrine PRL to breast tumorigenesis (Touraine et al. 1998, Vonderhaar 1999, Bhatavdekar et al. 2000, Llovera et al. 2000). High levels of serum PRL are associated with increased risk of breast cancer (Hankinson et al. 1999), recurrence of metastatic breast cancer and reduced survival time (Bhatavdekar et al. 2000). The hPRLR-SFlb is a strong dominant-negative to the differentiative function of the hPRLR-LF, leading us to hypothesize that it may regulate hPRLR-LF-mediated differentiation of breast epithelium. Heterozygous PRLR knockout mice with only one copy of the PRLR gene are unable to lactate following their first parturition, while homozygous knockouts never lactate (Ormandy et al. 1997). This demonstrates a unique sensitivity of the mammary gland to PRLR levels. Semiquantitative analysis of amplicon intensities in individual breast tumor samples suggested that 29 of 36 samples had higher levels of hPRLR-SFla than hPRLR-SF1b, although fully quantitative analysis remains to be performed. Preliminary semi-quantitative analysis also suggested that in the majority of breast tumor samples, the level of hPRLR-SFla mRNA was higher than in the matched normal tissue. Further confirmation of these results taking into account epithelial cell content remains to be performed. Further studies to elucidate the effects of hPRLR-SFla and hPRLRSF1b on PRL-induced mitosis will also help to define whether these isoforms play a role in endocrine or autocrine PRL-stimulated breast cancer growth.

Compared with the well-documented effects of the hPRLR-LF, neither hPRLR-SFla nor hPRLRSF $1 b$ transduced a differentiation signal to the $\beta$-casein promoter. Both box 1 and box 2 in the intracellular domain of the PRLR are necessary for activation of the Jak2/Stat5 pathway during differentiation (DaSilva et al. 1994, Pezet et al. 


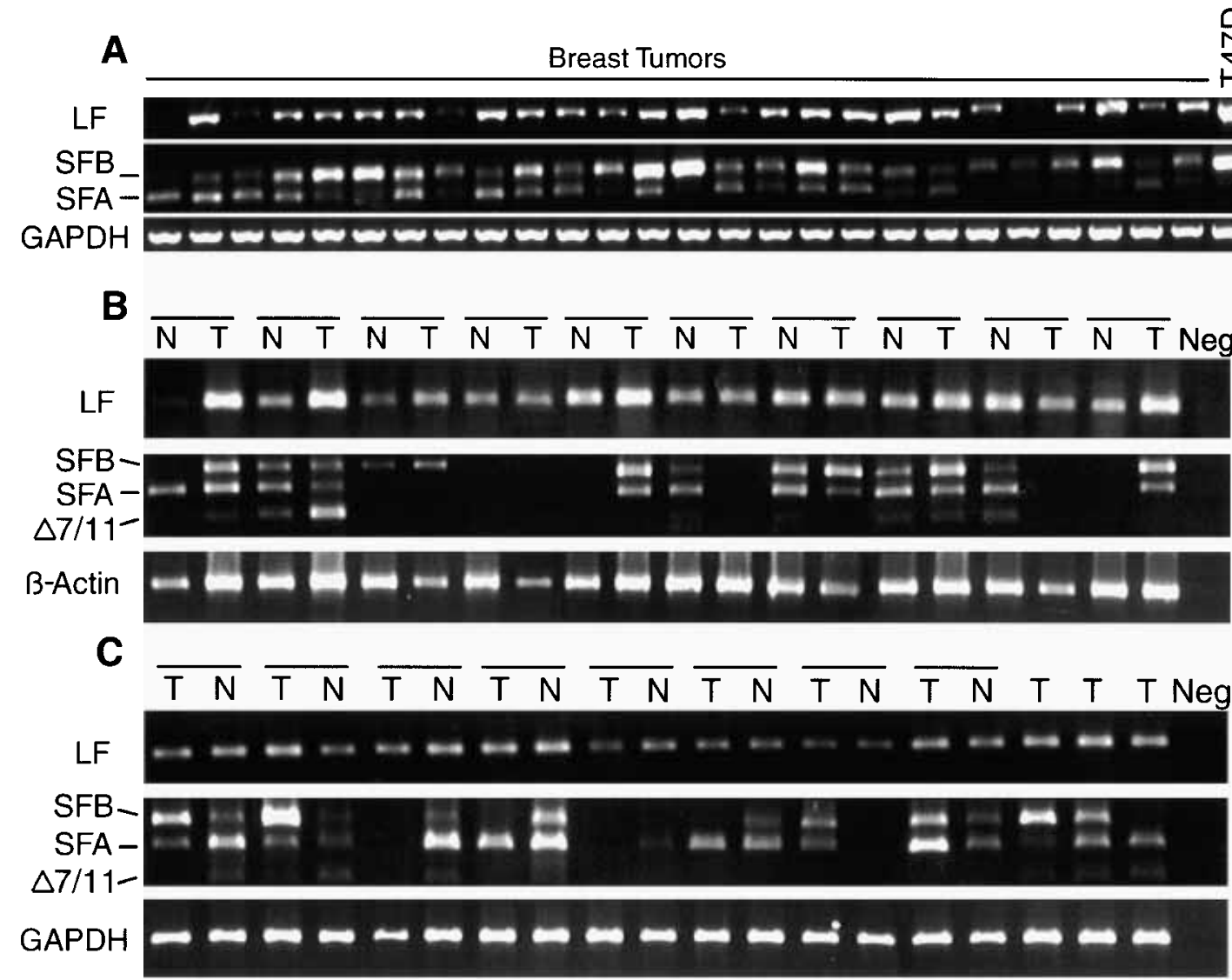

Figure 9 Expression of hPRLR short form 1a (SF1a), short form 1b (SF1b), $\Delta 7 / 11$ and long form (LF) mRNAs in normal and tumor samples of breast and colon as determined by RT-PCR. Amplification of cDNA gave consistent results in two independent RT-PCR reactions. Neg=negative control. (A) Human breast cancer samples. hGAPDH was amplified by RT-PCR as an internal control. (B) Matched pairs of normal and cancerous human breast tissue. $\beta$-Actin was amplified by RT-PCR as an internal control. (C) Matched pairs of normal and cancerous human colon tissue. hGAPDH was amplified by RT-PCR as an internal control. T, tumour; N, normal.

1997). The intracellular domains of the rat $\mathrm{Nb} 2 \mathrm{IF}$, human IF and hPRLR-SFla all contain box 1 and box 2 and are all approximately the same length. However, neither the human IF nor hPRLR-SFla has a tyrosine residue at or near position 382. This Y382 in the rat IF is absolutely necessary for PRL-responsive gene transcription (Lebrun et al. 1995). The human IF can activate Jak2 but cannot stimulate cell proliferation (Kline et al. 1999). hPRLR-SFla contains two tyrosine residues downstream from box 2 at positions Y347 and Y353 that are not present in the IF, and it remains to be tested whether hPRLR-SFla can initiate cell proliferation. It is conceivable that hPRLR-SFla, like the IF, can activate Jak2. PRL activation of
Jak2 leads to constitutive activation of ErbB2 (Yamauchi et al. 2000), a contributing factor in the growth of 25-40\% of breast cancers (Maguire \& Greene 1989), so this is an important question to be answered.

The novel splice variant $\Delta 7 / 11$ differs in size $(40 \mathrm{kDa})$ from the PRL-binding protein $(32 \mathrm{kDa})$ identified and more recently characterized in human serum and milk (Clandinin et al. 1986, Kline \& Clevenger 2001). $\Delta 7 / 11$ is expressed in normal and cancerous breast tissue, and therefore likely to be secreted in milk, and may be involved in regulating the function of PRL during breast tumorigenesis. Further determination of the tissue distribution of $\Delta 7 / 11$ is currently under 
investigation. It is noteworthy that the size of $\Delta 7 / 11$ differs between the secreted and intracellular forms and may reflect different posttranslational processing of the secreted protein. Differences in glycosylation have been observed previously between intracellular/membrane proteins and secreted proteins in CHO-K1 cells (Hooker et al. 1999, Morrison et al. 2000). Along these lines, the vesiculated intracellular distribution of $\Delta 7 / 11$ is of interest. Recently, $\mathrm{Hu}$ et al. (2001) identified that SFla, but not SF1b, is similarly distributed, raising the possibility that the $3^{\prime}$ sequence shared by $\Delta 7 / 11$ and $\mathrm{SF} 1$ a directs this localization.

It would appear that multiple poly $\mathrm{A}$ signals are present in exon 11 given that the poly (A)18 tail on our 3' RACE product was a further $233 \mathrm{bp}$ downstream of that reported by $\mathrm{Hu}$ et al. (2001). This phenomenon has been reported for numerous genes (Edwalds-Gilbert et al. 1997). Our analysis also indicates that $68 \mathrm{bp}$ of $3^{\prime}$ flanking sequence proposed by $\mathrm{Hu}$ et al. (2001) is actually transcribed $3^{\prime}$-UTR. It is intriguing that there was no consensus AATAAA polyadenylation site in the cDNA. This is not unprecedented because a small number of other mammalian mRNAs have been found with non-consensus polyadenylation sites (Sheets et al. 1990, Hirama et al. 1999), although these are less efficient in directing cleavage and polyadenylation (Sheets et al. 1990). The strength of a polyadenylation signal can directly influence the amount of mRNA transcribed (Edwalds-Gilbert et al. 1997), which may partially explain why the expression level of $\Delta 7 / 11$, hPRLR-SFla and hPRLR-SF1b mRNAs was lower than that for hPRLR-LF.

In the course of this study, we also identified two potentially non-functional PRLR isoforms that omit exon 4 but splice to exon 11. Previous works have described splice variants that lack exons 4 and 5 of the extracellular domain (Kline et al. 1999), exon 6 of the extracellular domain (Laud et al. 2000) and either exon 4, exons 5 and 6, or midway of exon 4 through midway of exon 6 (Nagano et al. 1995). Although these latter three variants were assumed to splice to exon 10, we have found isoforms with deletion of exon 4 that spliced in the same manner as either SF1b or $\Delta 7 / 11$. In addition, a splice variant that lacks part of exon 4 through to part of exon 6 and splices the same as SFla at the $3^{\prime}$ end (data not shown), that we have found, has a
5 bp repeat at the two splice sites, and the AG/GT splice site consensus does not apply. This rare 'splicing' could be a result of recombination (or template-switching) caused by RT (S Mount, personal communication).

We found that the addition of either hPRLRLF or hPRLR-SFla to a constant amount of hPRLR-SFlb decreased the total number of binding sites. Moreover, heterodimers of hPRLRLF:SF1b (1:1) had a slightly lower affinity for hGH than either hPRLR-SF1b or hPRLR-LF alone. The effect of heterodimerization on the affinity of receptors has been documented for a number of transmembrane cytokine receptors, where receptors of low and intermediate affinity can interact to form a high-affinity receptor (Hayashida et al. 1990, Kitamura et al. 1991, Goldstein et al. 1992). At this stage the mechanism behind the decrease in affinity for PRL by heterodimers of hPRLR-LF and hPRLR-SF $1 b$ and the effect on the total number of binding sites is not clear.

In conclusion, we have identified five isoforms of the hPRLR, two of which act as dominantnegatives to the differentiative function of the hPRLR-LF, while a third encodes a secreted PRL-binding protein. These isoforms are expressed independently and in different ratios by various human tissues and cell lines. The ratio of $\Delta 7 / 11$, hPRLR-SFla and hPRLR-SF1b mRNA expression in colon and breast cancer changes between normal and cancer states, suggesting that these isoforms may play a role in regulating the effects of endocrine and/or autocrine PRL - in normal and cancer cells.

\section{Acknowledgements}

The authors wish to thank David Salomon (NCI, $\mathrm{NIH}$ ), Robert Callahan (NCI, NIH) and Erika Ginsburg (NCI, NIH) for kindly providing tissue or RNA samples.

\section{References}

Berlanga JJ, Garcia-Ruiz JP, Perrot-Applanat M, Kelly PA \& Edery M 1997 The short form of the prolactin (PRL) receptor silences PRL induction of the beta-casein gene promoter. Molecular Endocrinology 11 1449-1457.

Bhatavdekar JM, Patel DD, Giri DD, Karelia NH, Vora HH, Ghosh N, Shah NG, Trivedi SN \& Balar DB 1992 Comparison of plasma prolactin and CEA in monitoring patients with adenocarcinoma of colon and rectum. British fournal of Cancer $\mathbf{6 6}$ 977-980. 
Bhatavdekar JM, Patel DD, Shah NG, Vora HH, Suthar TP, Ghosh N, Chikhlikar PR \& Trivedi TI 2000 Prolactin as a local growth promoter in patients with breast cancer: GCRI experience. European Fournal of Surgical Oncology 26 540-547.

Bignon C, Binart N, Ormandy CJ, Schuler LA, Kelly PA \& Djiane J 1997 Long and short forms of the ovine prolactin receptor: cDNA cloning and genomic analysis reveal that the two forms arise by different alternative splicing mechanisms in ruminants and in rodents. Fournal of Molecular Endocrinology 19 109-120.

Bignon C, Daniel N, Belair L \& Djiane J 1999 In vitro expression of long and short ovine prolactin receptors: activation of Jak2/STAT5 pathway is not sufficient to account for prolactin signal transduction to the ovine beta-lactoglobulin gene promoter. Fournal of Molecular Endocrinology 23 125-136.

Bole-Feysot C, Goffin V, Edery M, Binart N \& Kelly PA 1998 Prolactin (PRL) and its receptor: actions, signal transduction pathways and phenotypes observed in PRL receptor knockout mice. Endocrine Reviews 19 225-268.

Boutin JM, Jolicoeur C, Okamura H, Gagnon J, Edery M, Shirota M, Banville D, Dusanter-Fourt I, Djiane J \& Kelly PA 1988 Cloning and expression of the rat PRL receptor, a member of the growth hormone/prolactin receptor gene family. Cell $\mathbf{5 3}$ 69-77.

Boutin JM, Edery M, Shirota M, Jolicoeur C, Lesueur L, Ali S, Gould D, Djiane J \& Kelly PA 1989 Identification of a cDNA encoding a long form of PRL receptor in human hepatoma and breast cancer cells. Molecular Endocrinology 3 1455-1461.

Church GM \& Gilbert W 1984 Genomic sequencing. PNAS 81 1991-1995.

Clandinin MT, Chappell JE \& Mager D 1986 Prolactin binding protein in human milk. Endocrinologia Experimentalis 20 209-215.

Clevenger GV, Chang WP, Ngo W, Pasha TLM, Montone KTi \& Tomaszewski JE 1995 Expression of prolactin and prolactin receptor in human breast carcinoma. American Journal of Pathology 146 695-705.

Das R \& Vonderhaar BK 1995 Transduction of prolactin's (PRL) growth signal through both long and short forms of the PRL receptor. Molecular Endocrinology 9 1750-1759.

DaSilva L, Howard OMH, Rui H, Kirken RA \& Farrar WL 1994 Growth signaling and JAK2 association mediated by membrane-proximal cytoplasmic regions of prolactin receptors. Fournal of Biological Chemistry 269 18267-18270.

Davis JA \& Linzer DIH 1989 Expression of multiple forms of the prolactin receptor in mouse liver. Molecular Endocrinology 3 674-680.

Edwalds-Gilbert G, Veraldi KL \& Milcarek C 1997 Alternative poly(A) site selection in complex transcription units: means to an end? Nucleic Acids Research 25 2547-2561.

Genty N, Paly J, Edery M, Kelly PA, Djiane J \& Salesse R 1994 Endocytosis and degradation of prolactin and its receptor in Chinese hamster ovary cells stably transfected with prolactin receptor cDNA. Molecular and Cellular Endocrinology 99 221-228.

Ginsburg E \& Vonderhaar BK 1995 Prolactin synthesis and secretion by human breast cancer cells. Cancer Research $\mathbf{5 5}$ 2591-2595.

Goldstein B, Jones D, Kevrekidis IG \& Perelson AS 1992 Evidence for p55-p75 heterodimers in the absence of IL-2 from Scatchard plot analysis. International Immunology 4 23-32.

Hankinson SE, Wilett WC, Michaud DS, Manson JE, Colditz GA, Longcope C, Rosner B \& Speizer FE 1999 Plasma prolactin levels and subsequent risk of breast cancer in postmenopausal women. Fournal of the National Cancer Institute 91 629-634.

Hayashida K, Kitamura T, Gorman DM, Arai K, Yokota T \& Miyajima A 1990 Molecular cloning of a second subunit of the receptor for human granulocyte-macrophage colony-stimulating factor (GM-CSF): reconstitution of a high-affinity GM-CSF receptor. PNAS 87 9655-9659.
Hirama T, Miller CW \& Koeffler HP 1999 Translocon-associated protein alpha transcripts are induced by granulocyte-macrophage colony-stimulating factor and exhibit complex alternative polyadenylation. FEBS Letters $\mathbf{4 5 5} 223-227$.

Hooker AD, Green NH, Baines AJ, Bull AT, Jenkins N, Strange PG \& James DC 1999 Constraints on the transport and glycosylation of recombinant IFN-gamma in Chinese hamster ovary and insect cells. Biotechnology and Bioengineering 63 559-572.

Hu ZZ, Zhuang L, Meng J, Leondires M \& Dufau ML 1999 The human prolactin receptor gene structure and alternative promoter utilization: the generic promoter hPIII and a novel human promoter $\mathrm{hP}(\mathrm{N})$. Fournal of Clinical Endocrinology and Metabolism 84 1153-1156.

Hu ZZ, Meng J \& Dufau MLi 2001 Isolation and characterization of two novel forms of the human prolactin receptor generated by alternative splicing of a newly identified exon 11. Fournal of Biological Chemistry 276 41086-41094.

Hu ZZ, Zhuang L, Meng J, Tsai-Morris CH \& Dufau ML 2002 Complex 5' genomic structure of the human prolactin receptor: multiple alternative exons 1 and promoter utilization. Endocrinology 143 2139-2142.

Jabbour HN, Critchley HO \& Boddy SC 1998 Expression of functional prolactin receptors in nonpregnant human endometrium: janus kinase-2, signal transducer and activator of transcription-1 (STAT1), and STAT5 proteins are phosphorylated after stimulation with prolactin. Fournal of Clinical Endocrinology and Metabolism 83 2545-2553.

Kelly PA, Boutin JM, Jolicoeur C, Okamura H, Shirato M, Edery M, Dusanter-Fourt I \& Djiane J 1989 Purification, cloning, and expression of the prolactin receptor. Biology of Reproduction $\mathbf{4 0}$ $27-32$.

Kitamura T, Hayashida K, Sakamaki K, Yokota T, Arai K \& Miyajima A 1991 Reconstitution of functional receptors for human granulocyte/macrophage colony-stimulating factor (GM-CSF): evidence that the protein encoded by the AIC2B CDNA is a subunit of the murine GM-CSF receptor. PNAS $\mathbf{8 8}$ $5082-5086$

Kline JB \& Clevenger CV 2001 Identification and characterization of the prolactin-binding protein in human serum and milk. Fournal of Biological Chemistry 276 24760-24766.

Kline JB, Roehrs H \& Clevenger CV 1999 Functional characterization of the intermediate isoform of the human prolactin receptor. Fournal of Biological Chemistry 274 35461-35468.

Laud K, Gourdou I, Belair L, Peyrat J-P \& Djiane J 2000 Characterization and modulation of a prolactin receptor mRNA isoform in normal and tumoral human breast tissues. International Fournal of Cancer 85 771-776.

Lebrun JJ, Ali S, Goffin V, Ullrich A \& Kelly PA 1995 A single phosphotyrosine residue of the prolactin receptor is responsible for activation of gene transcription. PNAS 92 4031-4035.

Lesueur L, Edery M, Ali S, Paly J, Kelly PA \& Djiane J 1991 Comparison of long and short forms of the prolactin receptor on prolactin-induced milk protein gene transcription. PNAS $\mathbf{8 8}$ 824-828.

Llovera M, Pichard C, Bernichtein S, Jeay S, Touraine P, Kelly PA \& Goffin V 2000 Human prolactin (hPRL) antagonists inhibit hPRL-activated signaling pathways involved in breast cancer cell proliferation. Oncogene 19 4695-4705.

Maguire HC Jr \& Greene MI 1989 The neu (c-erbB-2) oncogene. Seminars in Oncology 16 148-155.

Morrison CJ, Easton RL, Morris HR, McMaster WR, Piret JM \& Dell A 2000 Modification of a recombinant GPI-anchored metalloproteinase for secretion alters the protein glycosylation. Biotechnology and Bioengineering 68 407-421.

Mount SM 1982 A catalogue of splice junction sequences. Nucleic Acids Research $10459-472$. 
Nagano M, Chastre E, Choquet A, Bara J, Gespach C \& Kelly PA 1995 Expression of prolactin and growth hormone receptor genes and their isoforms in the gastrointestinal tract. American Fournal of Physiology 268 G431-G442.

O'Neal KD \& Yu Lee L 1994 Differential signal transduction of the short, $\mathrm{Nb2}$, and long prolactin receptors. Fournal of Biological Chemistry $26926076-26082$.

Ormandy CJ, Binart N \& Kelly PA 1997 Mammary gland development in prolactin receptor knockout mice. Fournal of Mammary Gland Biology and Neoplasia 2 355-364.

Ormandy CJ, Binart N, Helloco C \& Kelly PA 1998 Mouse prolactin receptor gene: genomic organization reveals alternative promoter usage and generation of isoforms via alternative 3 '-exon splicing. DNA and Cell Biology 17 761-770.

Patel DD, Bhatavdekar JM, Ghosh N, Vora HH, Karelia NH, Shah NG, Suthar TP, Balar DB \& Trivedi CR 1994 Plasma prolactin in patients with colorectal cancer. Value in follow-up and as a prognosticator. Cancer 73 570-574.

Perrot-Applanat M, Gualillo O, Buteau H, Edery M \& Kelly PA 1997 Internalization of prolactin receptor and prolactin in transfected cells does not involve nuclear translocation. Fournal of Cell Science 110 1123-1132.

Pezet A, Buteau H, Kelly PA \& Edery M 1997 The last proline of Box 1 is essential for association with JAK2 and functional activation of the prolactin receptor. Molecular and Cellular Endocrinology 129 199-208.
Sheets MD, Ogg SC \& Wickens MP 1990 Point mutations in AAUAAA and the poly (A) addition site: effects on the accuracy and efficiency of cleavage and polyadenylation in vitro. Nucleic Acids Research 18 5799-5805.

Touraine P, Martini JF, Zafrani B, Durand JC, Labaille F, Malet C, Nicolas A, Trivin C, Postel-Vinay MC, Kuttenn F et al. 1998 Increased expression of prolactin receptor gene assessed by quantitative polymerase chain reaction in human breast tumors versus normal breast tissues. Fournal of Clinical Endocrinology and Metabolism 83 667-674.

Vonderhaar BK 1999 Prolactin involvement in breast cancer. Endocrine-Related Cancer 6 389-404.

Wennbo H, Gebre-Medhin M, Gritli-Linde A, Ohlsson C, Isaksson OGP \& Tornell J 1997 Activation of the prolactin receptor but not the growth hormone receptor is important for induction of mammary tumors in transgenic mice. Fournal of Clinical Investigation $1002744-2751$.

Yamauchi T, Yamauchi N, Ueki K, Sugiyama T, Waki H, Miki H, Tobe K, Matsuda S, Tsushima T, Yamamoto T et al. 2000 Constitutive tyrosine phosphorylation of ErbB-2 via Jak2 by autocrine secretion of prolactin in human breast cancer. Fournal of Biological Chemistry 275 33937-33944.

Received in final form 14 August 2002 Accepted 16 September 2002 